\title{
Evidence of West Nile virus infection in Nepal
}

\author{
Wiriya Rutvisuttinunt ${ }^{1 *}$, Piyawan Chinnawirotpisan', Chonticha Klungthong ${ }^{1}$, Sanjaya Kumar Shrestha², \\ Amod Bahadur Thapa ${ }^{3}$, Arjun Pant ${ }^{4}$, Samuel L Yingst ${ }^{1}$, In-Kyu Yoon ${ }^{1}$, Stefan Fernandez ${ }^{1}$ and Julie A Pavlin ${ }^{5^{*}}$
}

\begin{abstract}
Background: Acute febrile illness is common among those seeking medical care and is frequently treated empirically with the underlying illness remaining undiagnosed in resource-poor countries. A febrile illness study was conducted 2009-2010 to identify known and unknown pathogens circulating in Nepal.

Method: Study methods included diagnostic testing and preliminary ELISA screening of acute and convalescent samples for diseases both known and unknown to be circulating in Nepal, including West Nile virus (WNV). The molecular assays including Polymerase Chain Reaction (PCR), Sanger sequencing and ultra deep sequencing on MiSeq Illumina Platform were conducted to further confirm the presence of WNV.

Results: The study enrolled 2,046 patients presenting undifferentiated febrile illness with unknown etiology. Sera from 14 out of 2,046 patients were tested positive for west nile virus (WNV) by nested Reverse Transcription-Polymerase Chain Reaction (RT-PCR). Only two out of 14 cases were confirmed for the presence of WNV by sequencing and identified as WNV lineage 1 phylogentically. The two patients were adult males with fever and no neurological symptoms from Kathmandu and Bharatpur, Nepal.
\end{abstract}

Conclusion: Two out of 2,046 serum samples contained fragments of WNV genome resembling WNV lineage 1, which is evidence of the continued spread of WNV which should be considered a possible illness cause in Nepal.

Keywords: West nile virus, Nepal, Febrile illness, Deep sequencing, NGS, Phylogeny

\section{Background}

West Nile virus (WNV) is one of 70 members of the Flavivirus genus which are serologically characterized by eight antigenic complexes and nine serotypes [1]. WNV can cause neuroinvasive disease and febrile illnesses resulting in substantial morbidity and mortality in humans and other vertebrates.

WNV is classified phylogenetically into eight different lineages with two main lineages causing outbreaks in humans. Lineage 1 is mostly found in India, Australia, the Middle East, Europe and North America, while lineage 2 is mainly found in sub-Saharan Africa, Europe and the island of Madagascar. Sub-lineages III, IV, V, VI and VIII from lineage 1 are further segregated into distinct regions [2]. WNV has been reported in East Asia including India and China [3,4]. Although no human cases have been reported, the WNV-carrying Culex mosquito vector can be found in Nepal [5]. In 2006, Pant et al.

\footnotetext{
* Correspondence: wiriyar@afrims.org; julie.a.pavlin.civ@mail.mil

${ }^{1}$ Armed Forces Research Institute of Medical Sciences, Bangkok, Thailand

${ }^{5}$ Armed Forces Health Surveillance Center, Silver Spring, Maryland, USA

Full list of author information is available at the end of the article
}

reported neutralizing antibodies against Kunjin virus in porcine sera in Nepal, which is a subtype of WNV [6].

Here, we report the presence of WNV RNA by nested Reverse Transcription-Polymerase Chain Reaction (nested RT-PCR) and further subtyped by deep sequencing from the acute sera of two febrile individuals, without neurological symptoms enrolled in a febrile illness study conducted in Nepal from May 2009 to December 2010.

\section{Methods}

A total of 2,046 clinical specimens were collected from the febrile illness study at 4 hospitals in 3 cities in Nepal during May 2009 to December 2010. The patients presented with undifferentiated febrile illness with no known etiology. Fourteen acute specimens, from patients whose convalescent samples were WNV antibody positive by Panbio ${ }^{(\mathrm{R})}$ West Nile Virus IgM Capture ELISA (Alere, GA, USA) (which can have $12.5 \%$ cross-reactivity with dengue), were tested by RT-PCR to detect WNV RNA. These serum specimens were collected from febrile volunteers in Kathmandu and Bharatpur (Figure 1) and tested for WNV using a nested RT-PCR adapted from methods previously reported $[7,8]$. The febrile 


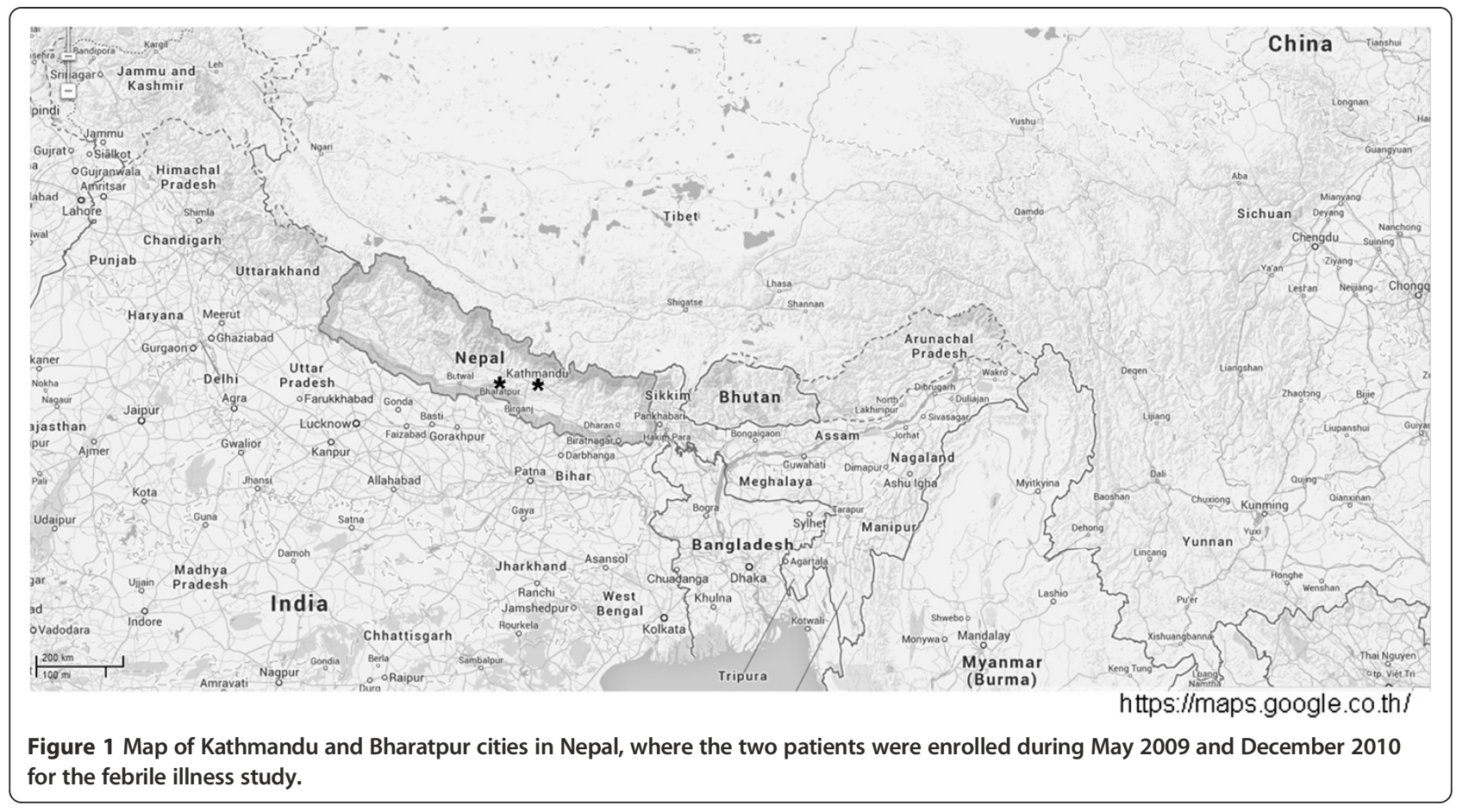

illness study was approved by the institutional review boards of the Nepal Health Research Council and Walter Reed Army Institute of Research under WRAIR protocol \# 1513, and was performed in compliance with the Helsinki Declaration.

RNA from WNV serum was extracted followed by conventional nested RT-PCR. Sample preparation for deep sequencing using MiSeq followed as previously described [9], with an additional centrifugation step at 6,200 $\mathrm{g}$ for 10 minutes at $4^{\circ} \mathrm{C}$, and DNaseI (PreAnalytiX, QIAGEN, Franklin Lakes, USA) treatment at $37^{\circ} \mathrm{C}$ for 15 minutes. Sequence reads with at least Q30 score were trimmed to remove adaptor sequences and analyzed as described in [10]. WNV sequence was identified by de novo assembly with Trinity followed by Blast or read-mapping align with WNV references (Figure 2). WNV references used in the alignment analysis and maximum likelihood phylogenetic tree were retrieved from GenBank as described, (Figure 2) and the pair-wise genetic distance was calculated using reference strains from lineage 1a and 2 (Table 1). Our sequences were submitted to GENBANK: KJ599821-2 for lineage 1 and 2 for VIROAF73 and KJ599823-4 for lineage 1 and 2 for VIROAF74, respectively.

\section{Results and discussion}

Of 2,046 patients with acute febrile illness without neurological symptoms, 14 had convalescent blood samples positive for WNV antibody by ELISA with most (as there was one DEN positive) excluded for DEN and JE. Only 2 out of 14 samples, identified as VIROAF73 and VIROAF74, showed the presence of WNV RNA by nested RT-PCR with product bands migrating around 104-105 bp as shown by the positive control, WNV Egypt 1951 strain (EU081844). The VIROAF74 104-105 bp amplicon was sequenced to confirm the presence of $\mathrm{WNV}$.

VIROAF73 was obtained from a young adult male student who presented five days after onset of illness in Kathmandu. The temperature, pulse, blood pressure and respiratory rate were measured as $38^{\circ} \mathrm{C}, 100 /$ minute pulse, $100 / 70$ and $22 /$ minute, respectively. His symptoms included anorexia, chills, fever, headache, malaise and muscle aches. The physical examination was remarkable only for abdominal tenderness. There were no reported tick bites, animal exposures or contacts with a person with similar symptoms. On presentation, he had been taking paracetamol and Ayurvedic for 5 days. He reported no significant past medical history. He lived in the urban area of Kathmandu and had no recent travel history.

VIROAF74 was obtained from a middle-aged male in the service industry who was hospitalized in Bharatpur seven days after onset of illness. His symptoms included abdominal cramps, fatigue, fever, headache and malaise with joint and retro-orbital pain. His temperature, pulse, blood pressure and respiratory rate were $40.3^{\circ} \mathrm{C}$, $100 /$ minute, $100 / 70$ and $20 /$ minute. The physical examination indicated that he was pale and lethargic with no obvious tick bites. He had exposure to cattle and buffalo and had contact with a household member with similar symptoms. He had not traveled outside of Bharatpur, which is an urban center near the border with India. His treatment at time of presentation included Cefixime $200 \mathrm{mg}$ tablet BD for 5 days. He had no significant past 


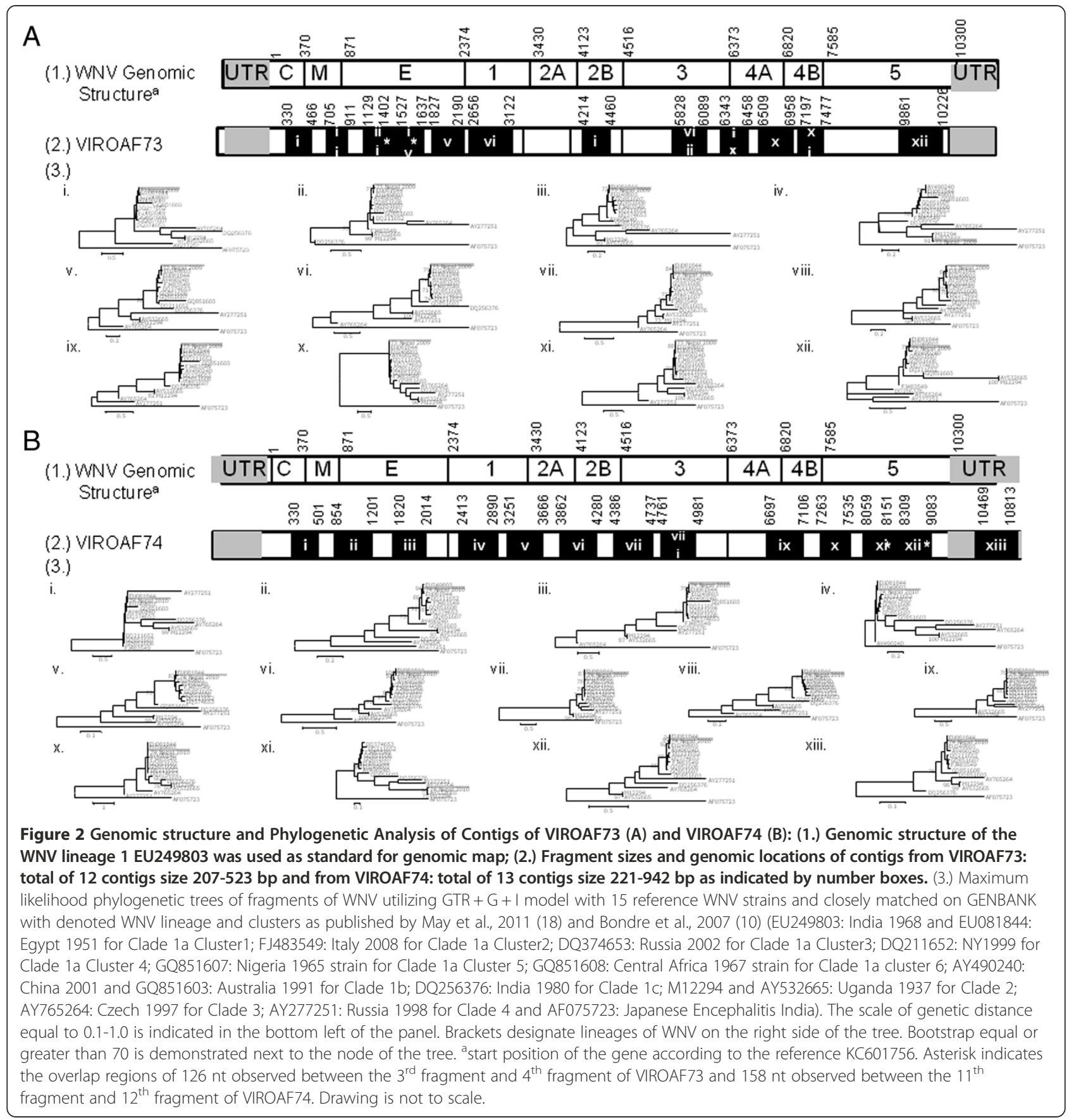

medical history. He was also found to have a potential acute secondary dengue infection based on elevated dengue IgM and IgG antibodies with IgM: IgG ratio $<1.8$ which remained elevated, although slightly decreased, in his convalescent specimen. This could represent a co-infection or cross-reactive elevation of pre-existing dengue antibodies upon immune boosting with another flavivirus.

Deep sequencing was conducted on both VIROAF73 and VIROAF74 sera. Following the pathogen identification algorithm, both read-mapping alignment and de novo assembly procedures identified several fragments aligning with the WNV genome. Overall, approximately $36 \%$ of the WNV genomic sequence was found in VIROAF73 and 44\% in VIROAF74 (Figure 2). A total of 1306 bp covered over nine overlapping regions between VIROAF73 and VIROAF74, which had 97.0\%-100.0\% nucleotide identity. For VIROAF73, a total of 12 contig fragments with sizes ranging from 116 to $450 \mathrm{bp}$ were mapped from the 5' end to the 3' end of the WNV genomes. Eleven of 12 contig fragments fell in the same group of WNV lineage 1a (Figure 2A and 
Table 1 Genetic distance of the WNV sequence fragments from the lineage $1 \mathrm{a}$ and 2 reference strains

\begin{tabular}{|c|c|c|c|c|c|c|}
\hline \multirow[t]{3}{*}{ Specimen ID. } & \multirow[t]{3}{*}{ Fragment ID. } & \multirow{3}{*}{$\begin{array}{l}\text { Fragment } \\
\text { length (bp) }\end{array}$} & \multicolumn{4}{|c|}{ Genetic distance $(p-$ distance $)+$} \\
\hline & & & \multicolumn{2}{|l|}{ Lineage $1 \mathrm{a}$} & \multicolumn{2}{|l|}{ Lineage 2} \\
\hline & & & $\begin{array}{l}\text { EU081844 } \\
\text { Egypt } 1951\end{array}$ & $\begin{array}{l}\text { EU249803 } \\
\text { India } 1968\end{array}$ & $\begin{array}{l}\text { M12294 } \\
\text { Uganda } 1937\end{array}$ & $\begin{array}{l}\text { AY532665 } \\
\text { Uganda } 1937\end{array}$ \\
\hline \multirow[t]{12}{*}{ VIROAF73 } & i. & 297 & 0.000 & 0.000 & 0.226 & 0.0234 \\
\hline & ii. & 207 & 0.000 & 0.000 & 0.189 & 0.184 \\
\hline & iii. & 400 & 0.003 & 0.003 & 0.229 & 0.229 \\
\hline & iv. ${ }^{a}$ & 236 & 0.242 & 0.242 & 0.013 & 0.004 \\
\hline & v. & 364 & 0.000 & 0.008 & 0.206 & 0.206 \\
\hline & vi. & 467 & 0.000 & 0.000 & 0.221 & 0.218 \\
\hline & vii. & 270 & 0.056 & 0.056 & 0.211 & 0.219 \\
\hline & viii. & 262 & 0.011 & 0.011 & 0.229 & 0.229 \\
\hline & ix. & 208 & 0.000 & 0.000 & 0.216 & 0.207 \\
\hline & $\mathrm{x}$ & 450 & 0.007 & 0.007 & 0.258 & 0.258 \\
\hline & $x i$ & 281 & 0.000 & 0.000 & 0.224 & 0.224 \\
\hline & xii. & 523 & 0.048 & 0.048 & 0.225 & 0.225 \\
\hline \multirow[t]{13}{*}{ VIROAF74 } & i. & 270 & 0.000 & 0.000 & 0.233 & 0.238 \\
\hline & ii. & 401 & 0.083 & 0.085 & 0.261 & 0.261 \\
\hline & iii. & 252 & 0.129 & 0.133 & 0.325 & 0.325 \\
\hline & iv. & 492 & 0.018 & 0.020 & 0.226 & 0.226 \\
\hline & v. & 473 & 0.010 & 0.010 & 0.185 & 0.185 \\
\hline & vi & 419 & 0.005 & 0.005 & 0.232 & 0.234 \\
\hline & vii. & 352 & 0.006 & 0.006 & 0.179 & 0.179 \\
\hline & viii. & 221 & 0.000 & 0.000 & 0.213 & 0.213 \\
\hline & ix. & 410 & 0.002 & 0.002 & 0.242 & 0.24 \\
\hline & $x$ & 376 & 0.015 & 0.015 & 0.249 & 0.249 \\
\hline & $x i^{a}{ }^{a}$ & 252 & 0.239 & 0.239 & 0.016 & 0.008 \\
\hline & xii. & 942 & 0.007 & 0.008 & 0.203 & 0.203 \\
\hline & xiii. & 345 & 0.006 & 0.006 & 0.109 & 0.106 \\
\hline
\end{tabular}

+Closely related sequence to VIROAF73 \& VIROAF74 by blastn on GENBANK: Lineage 1a Reference Strains: Egypt 1951 (EU081844) and India 1968 (EU249803) and Lineage 2 Uganda 1937 (M12294 and AY532665).

${ }^{\text {a}}$ Fragments identified to be closely related to Lineage 2 .

Numbers in bold indicate the differences of genetic distance from the Egypt 1951 (EU081844) and India 1968 (EU249803).

Table 1). Similarly, for VIROAF74, 12 out of 13 contig fragments with sizes ranging from 172 to $933 \mathrm{bp}$ were grouped with WNV lineage 1a (Figure $2 \mathrm{~B}$ and Table 1). The sequences of these VIROAF73 and VIROAF74 fragments were slightly different from the lineage 1a reference strains (Table 1), which had nine regions of 1306 bp in length overlap with an average of $0.007(0.000-0.030)$ pair-wise distance between them. Contig 4 of VIROAF73 aligned with an envelope region of WNV which shared more similarity with lineage 2 of WNV than lineage 1 (Figure 3). The same was observed with contig 11 of VIROAF74 which aligned with the NS5 gene of WNV (Figure 3).

\section{Conclusions}

Our study identified two cases of WNV infection by advanced molecular and 14 probable cases by serological techniques from a study that enrolled 2,046 febrile illness patients in Nepal from May 2009 to December 2010. Initial evidence of WNV in the specimens was provided by nested PCR amplicons co-migrating with the WNV positive control. Further analyses of the sequences obtained using deep sequencing corroborated the presence of WNV.

In both patients, the convalescent sera also contained WNV antibodies as determined by Panbio ${ }^{(\mathrm{R})}$ West Nile Virus IgM Capture ELISA, suggesting the clinical specimens were collected during the declining stage of WNV viremia [11]. Despite incomplete WNV sequence recovered by deep sequencing, possibly due to low WNV viremia in the clinical specimens, fragment sequences obtained from VIROAF73 and VIROAF74 are likely WNV lineage 1 as determined by de novo assembly and alignment with WNV Egypt strain 101. Using Blastn and GENBANK sequences 


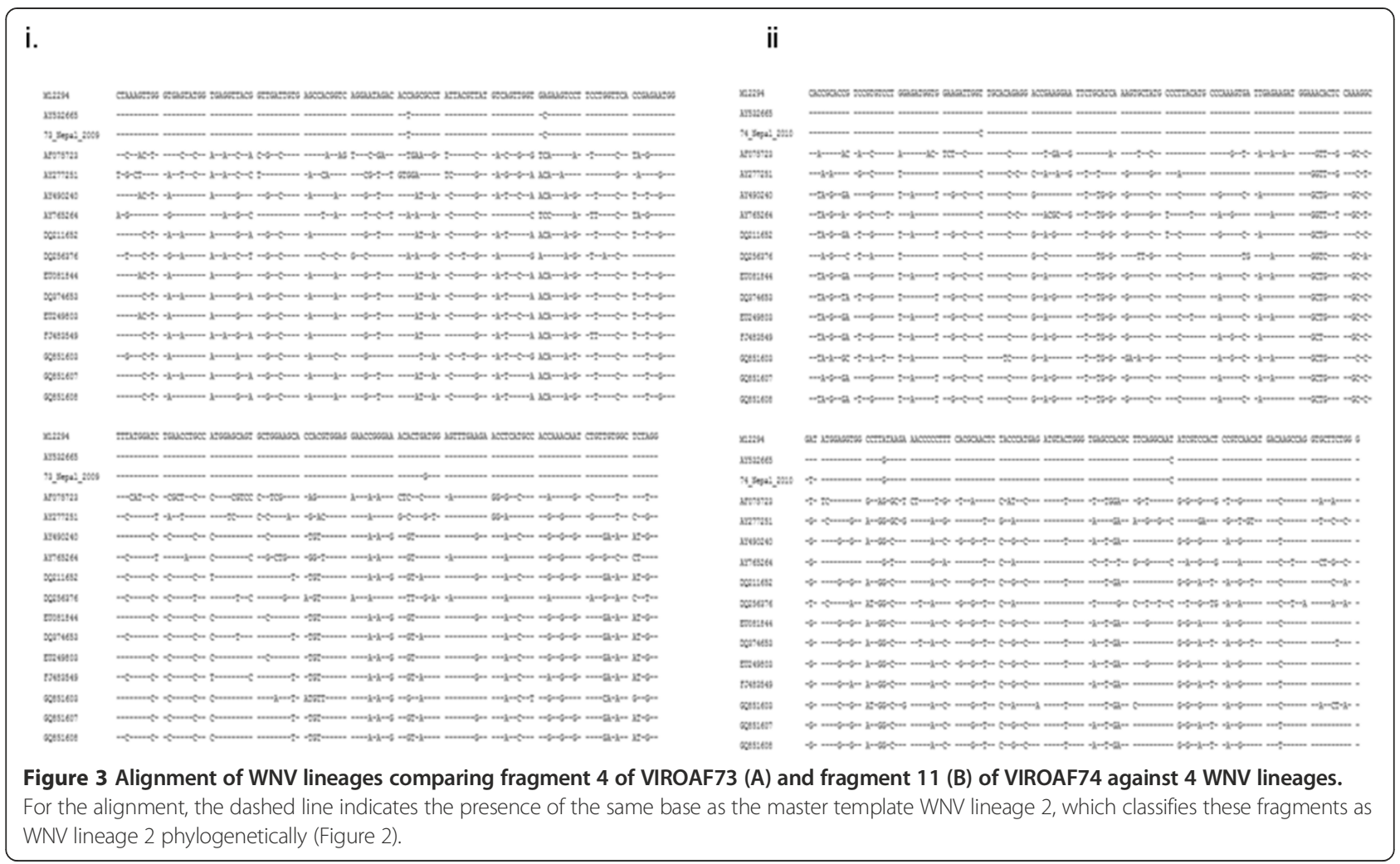

we found that almost all contigs (11/12 fragments of VIROAF73 and 12/13 fragments of VIROAF74) were closely related to WNV lineage 1a cluster 1 from India (strain 68856) and from Egypt (strain 101) and less so to strain China 2001 [2].

Nonetheless, the presence of sequences obtained from VIROAF73 (envelope) and from VIROAF74 (NS5B), which aligned with WNV lineage 2 (Figure 3), suggests that the WNV in the two specimens might be of a distinct strain since WNV lineage 2 is usually found in sub-Saharan Africa and Madagascar. WNV lineage 2 isolates have also been identified in South Africa [12], Hungary [13], and Russia [2]. The detection of a small portion of lineage 2 in lineage 1a backbone in VIROAF73 and VIROAF74 in Nepal suggests the presence of two lineages of WNV in both specimens. The detection of more than two lineages of WNV has been previously reported [14-16]. This may be associated with introduction by migratory birds as has been suggested in other settings [2].

The presence of WNV in two acute serum samples collected from Kathmandu and Bharatpur demonstrates the expansion of the virus to Nepal. Similarly, other vector borne diseases have recently been detected in Nepal for the first time, such as dengue virus, first detected in 2008, although much of Nepal is at a higher altitude than other endemic areas [17]. The detection of these distinct WNV strains from individuals without neurological symptoms represents the identification of a new etiology for acute febrile illness in Nepal. In a country endemic for another flavivirus, Japanese encephalitis, it can also be useful to consider WNV infection with acute central nervous system infection.

\section{Consents}

Written informed consent was obtained from the patient for participation in the febrile illness study. A copy of the written consent is available for review by the Editor of this journal.

\section{Competing interests}

The authors declare that they have no competing interests.

\section{Authors' contributions}

Conceived, designed and supported the study: WR, PC, CK, SLY, IY, SF, SKS, ABT, AP, JAP. Collected the data: WR, PC, SKS, ABT, AP. Analyzed the data: WR, PC, CK, IY, SF, JAP Wrote the paper: WR, PC, CK, SLY, IY, SF, SKS, ABT, AP, JAP. All authors read and approved the final manuscript.

\section{Acknowledgements}

We would like to thank Armed Forces Health Surveillance Center - Global Emerging Infections Surveillance and Response System (AFHSC-GEIS) for financial support, staff at WARUN for subject enrolment, sample processing and information management, staff at AFRIMS for clinical information, processing WNV isolates and laboratory technical assistance on nucleic acid measurement, and the bioinformatics team at Los Alamos National Laboratory, Naval Medical Research Center and Prince of Songkla University for Bioinformatics consultation. The views expressed in this article are those of the authors and do not represent the official policy or position of the US Department of the Army, Department of Defense, or US Government. 


\section{Author details}

${ }^{1}$ Armed Forces Research Institute of Medical Sciences, Bangkok, Thailand. ${ }^{2}$ Walter Reed/AFRIMS Research Unit Nepal, Kathmandu, Nepal. 'BBharatpur Hospital, Chitwan, Nepal. ${ }^{4}$ Sukra Raj Tropical Infectious Diseases Hospital, Kathmandu Nepal. ${ }^{5}$ Armed Forces Health Surveillance Center, Silver Spring, Maryland, USA.

Received: 25 March 2014 Accepted: 31 October 2014

Published online: 27 November 2014

\section{References}

1. Zanotto PM, Gould EA, Gao GF, Harvey PH, Holmes EC: Population dynamics of flaviviruses revealed by molecular phylogenies. Proc Nat Acad Sci U S A 1996, 93(2):548-553.

2. May FJ, Davis CT, Tesh RB, Barrett AD: Phylogeography of West Nile virus: from the cradle of evolution in Africa to Eurasia, Australia, and the Americas. J Virol 2011, 85(6):2964-2974

3. Chowdhury P, Khan SA, Dutta P, Topno R, Mahanta J: Characterization of West Nile virus (WNV) isolates from Assam, India: insights into the circulating WNV in northeastern India. Comp Immunol Microbiol Infect Dis 2013, 37(1):39-47.

4. Li XL, Fu SH, Liu WB, Wang HY, Lu Z, Tong SX, Li ZX, Nasci RS, Kosoy O, Cui $Y$, Liang GD: West nile virus infection in Xinjiang. China Vector Borne Zoonotic Dis 2013, 13(2):131-133.

5. Joshi G, Pradhan S, Darsie J, Richard F: Culicine, Sabethine and Toxorhynchitine mosquitoes of Nepal including new country records. Entomological Society of Washington 1965, 67:137-146.

6. Pant GR, Lunt RA, Rootes CL, Daniels PW: Serological evidence for Japanese encephalitis and West Nile viruses in domestic animals of Nepal. Comp Immunol Microbiol Infect Dis 2006, 29(2-3):166-175.

7. Lanciotti RS, Kerst AJ, Nasci RS, Godsey MS, Mitchell CJ, Savage HM, Komar N, Panella NA, Allen BC, Volpe KE, Davis BS, Roehrig JT: Rapid detection of west nile virus from human clinical specimens, field-collected mosquitoes, and avian samples by a TaqMan reverse transcriptase-PCR assay. J Clin Microbiol 2000, 38(11):4066-4071.

8. Shi PY, Kauffman EB, Ren P, Felton A, Tai JH, Dupuis AP 2nd, Jones SA, Ngo KA, Nicholas DC, Maffei J, Ebel GD, Bernard KA, Kramer LD: High-throughput detection of West Nile virus RNA. J Clin Microbio/ 2001, 39(4):1264-1271.

9. Rutvisuttinunt W, Chinnawirotpisan P, Simasathien S, Shrestha SK, Yoon IK, Klungthong C, Fernandez S: Simultaneous and complete genome sequencing of influenza $A$ and $B$ with high coverage by Illumina MiSeq Platform. J Virol Methods 2013, 193(2):394-404.

10. Culture-Free Detection and Identification of Unknown RNA Viruses. http://applications.illumina.com/content/dam/illuminamarketing/ documents/products/appnotes/appnote afrims rna viruses.pdf.

11. Busch MP, Kleinman SH, Tobler LH, Kamel HT, Norris PJ, Walsh I, Matud JL, Prince HE, Lanciotti RS, Wright DJ, Linnen JM, Caglioti S: Virus and antibody dynamics in acute west nile virus infection. J Infect Dis 2008, 198(7):984-993.

12. Burt FJ, Grobbelaar AA, Leman PA, Anthony FS, Gibson GV, Swanepoel R: Phylogenetic relationships of southern African West Nile virus isolates. Emerg Infect Dis 2002, 8(8):820-826.

13. Erdelyi K, Ursu K, Ferenczi E, Szeredi L, Ratz F, Skare J, Bakonyi T: Clinical and pathologic features of lineage 2 West Nile virus infections in birds of prey in Hungary. Vector Borne Zoonotic Dis 2007, 7(2):181-188.

14. Bakonyi T, Ivanics E, Erdelyi K, Ursu K, Ferenczi E, Weissenbock H, Nowotny N: Lineage 1 and 2 strains of encephalitic West Nile virus, central Europe. Emerg Infect Dis 2006, 12(4):618-623.

15. Bondre VP, Jadi RS, Mishra AC, Yergolkar PN, Arankalle VA: West Nile virus isolates from India: evidence for a distinct genetic lineage. J Gen Virol 2007, 88(Pt 3):875-884.
16. Lvov DK, Butenko AM, Gromashevsky VL, Kovtunov Al, Prilipov AG, Kinney R, Aristova VA, Dzharkenov AF, Samokhvalov El, Savage HM, Shchelkanov MY, Galkina IV, Deryabin PG, Gubler DJ, Kulikova LN, Alkhovsky SK, Moskvina TM, Zlobina LV, Sadykova GK, Shatalov AG, Lvov DN, Usachev VE, Voronina AG: West Nile virus and other zoonotic viruses in Russia: examples of emerging-reemerging situations. Arch Virol Suppl 2004, 18:85-96.

17. Takasaki T, Kotaki A, Nishimura K, Sato Y, Tokuda A, Lim CK, Ito M, Tajima S, Nerome R, Kurane I: Dengue virus type 2 isolated from an imported dengue patient in Japan: first isolation of dengue virus from Nepal. J Travel Med 2008, 15(1):46-49.

doi:10.1186/s12879-014-0606-0

Cite this article as: Rutvisuttinunt et al:: Evidence of West Nile virus infection in Nepal. BMC Infectious Diseases 2014 14:606.

\section{Submit your next manuscript to BioMed Central and take full advantage of:}

- Convenient online submission

- Thorough peer review

- No space constraints or color figure charges

- Immediate publication on acceptance

- Inclusion in PubMed, CAS, Scopus and Google Scholar

- Research which is freely available for redistribution

Submit your manuscript at www.biomedcentral.com/submit
C Biomed Central 